\title{
A NEW LINEAGE OF LICHENIZED BASIDIOMYCETES INFERRED FROM A TWO-GENE PHYLOGENY: THE LEPIDOSTROMATACEAE WITH THREE SPECIES FROM THE TROPICS ${ }^{1}$
}

\author{
Damien Ertz, ${ }^{2,6}$ James D. Lawrey, ${ }^{3}$ Masoumeh Sikaroodi, ${ }^{3}$ Patrick M. Gillevet, ${ }^{3}$ \\ Eberhard Fischer, ${ }^{4}$ Dorothee Killmann, ${ }^{4}$ and Emmanuël SérusiauX ${ }^{5}$
}

\begin{abstract}
${ }^{2}$ National Botanical Garden of Belgium, Domaine de Bouchout, B-1860 Meise, Belgium; ${ }^{3}$ Department of Environmental Science and Policy, George Mason University, 4400 University Drive, Fairfax, Virginia 22030-4444 USA; ${ }^{4}$ Institute for Integrated Natural Sciences, Department of Biology, University Koblenz-Landau, Universitätstraße 1, D-56070 Koblenz, Germany; and ${ }^{5}$ Plant Taxonomy and Conservation Biology Unit, University of Liège, Sart Tilman B22, B-4000 Liège, Belgium

The lichen habit has apparently evolved independently in at least five major clades of mushroom-forming basidiomycetes (Agaricomycetes). Tracing the origin of lichenization in these groups depends on a clearer understanding of the phylogenetic relationships of basidiolichens to other fungi. We describe here a new family of basidiolichens made up of tropical, soil-inhabiting fungi that form lichenized, scale-like squamules and erect, coral-like fruiting structures. These structures are common to two basidiolichen genera, Multiclavula and Lepidostroma. Molecular studies have confirmed the phylogenetic position of Multiclavula species in the Cantharellales, but Lepidostroma species have never been sequenced. We obtained nuclear small and large subunit ribosomal sequences from specimens of L. calocerum collected in Costa Rica and Mexico and also from specimens of two Multiclavula spp. recently described from Rwanda. The phylogenetic placement of these fungi within the Agaricomycetes was investigated using likelihood and Bayesian analyses. Our results indicate that L. calocerum and the Rwandan species form a natural group unrelated to Multiclavula and sister to the Atheliales, members of which are neither lichen-forming nor clavarioid. The independent evolution of morphologically similar forms in so many groups of basidiomycetes is a remarkable example of convergence, indicating similar pathways to lichenization in these fungi.
\end{abstract}

Key words: Africa; Agaricales; Atheliales; basidiomycetes; Lepidostroma; lichens; Multiclavula; neotropics; rDNA sequence analyses; symbiosis.

In this paper, we report that two recently discovered terricolous basidiomycetes belong to a previously unknown lichenized lineage. In addition to clarifying relationships among lichenized basidiomycetes, our paper demonstrates the need for study of lichen biodiversity in tropical areas, which remain very much unexplored. Indeed, as shown by Nelsen et al. (2007) and Lücking (2008), uncertainty about the total number of lichen species on earth is due primarily to the lack of data in tropical taxa, especially the lack of modern taxonomic treatments. Further, savannas and open dry forests represent neglected biomes in tropical Africa, and their lichen flora is virtually unknown, especially saxicolous and terricolous species. Although representing a large proportion of the protected areas in the continent, they are currently under threat due to inappropriate management (Burgess et al., 2004).

Less than $0.5 \%$ of described lichen-forming fungi belong to the Basidiomycota (Honegger, 1996), and all are mushroomforming basidiomycetes (Agaricomycetes) that associate with cyanobacteria or green algae. The morphological diversity of these lichens is assumed to derive from independent evolution of the lichen-forming habit from non-lichen ancestors, and recent molecular phylogenetic studies (Larsson et al., 2006;

1 Manuscript received 8 July 2008; revision accepted 26 September 2008.

The authors thank F. Bungartz, J.-P. Duvivier, D. Genney, R. Lücking, and R. Walleyn for providing images of the basidiolichens in Fig. 1. C. Gerstmans and W. Baert are thanked for technical assistance. Financial support was received from the Fonds National de la Recherche Scientifique (FNRS) from Belgium.

${ }_{6}$ Author for correspondence (e-mail: damien.ertz@br.fgov.be)

doi:10.3732/ajb.0800232
Larsson, 2007; Lawrey et al., 2007; Nelsen et al., 2007; J. Lawrey et al., unpublished manuscript) now indicate that they can be placed in as many as five different major groups of Agaricomycetes (Table 1).

Figure 1 shows the diversity of forms among accepted genera of basidiolichens (Oberwinkler 1970, 1984, 2001; Redhead et al. 2002a, b). Basidiolichens can be crustose, squamulose (scale-like) or foliose. Some species are Multiclavula-like, resembling coral fungi, others are omphalinoid, producing mushrooms with decurrent gills, or appearing as bracket fungi, or crust-like resupinate basidiomata. The first molecular phylogeny that included basidiolichens (Gargas et al., 1995) confirmed a long-held hypothesis that the lichen habit has evolved several times in the basidiomycetes, and studies done since that time have begun to clarify the composition and evolutionary development of the lichen-forming groups. In the mushroom-forming Agaricales, two common and relatively diverse genera, the omphalinoid chlorolichen Lichenomphalia and the bracket-forming cyanolichen Dictyonema, are now confirmed as closely related members of the Hygrophoraceae in the Agaricales (Lutzoni and Vilgalys, 1995; Lutzoni, 1997; Redhead et al., 2002a; Lodge et al., 2006; J. Lawrey et al., unpublished manuscript). The genus Multiclavula, forming coral-like fruiting structures, has long been recognized as a core member of the order Cantharellales, which includes a wide variety of nutritional forms in addition to lichen-formers (Binder et al., 2005; Lawrey et al., 2007; Nelsen et al., 2007). In the Corticiales, the squamulose basidiolichen Marchandiomphalina foliacea is the only lichen-forming species in that order, nested within a diverse group of saprotrophs and pathogens (Diederich and Lawrey, 2007; Lawrey et al., 2008). Some associations, especially those of Athelia, Athelopsis, Cyphellostereum, 
TABLE 1. The genera of basidiolichens, updated from a summary originally published by Nelsen et al. (2007). Genera in bold are truly lichenized. The others are considered to be weakly or doubtfully lichenized.

\begin{tabular}{|c|c|c|}
\hline Taxon & Systematic position & References \\
\hline Acantholichen & Hygrophoraceae (Agaricales) & Jørgensen (1998), J. Lawrey et al. (unpublished) \\
\hline Athelia & Atheliales, polyphyletic & $\begin{array}{l}\text { Poelt and Jülich (1969), Larsson et al. (2004), Larsson } \\
\text { (2007), loosely associated with green algae }\end{array}$ \\
\hline Athelopsis & Atheliales, polyphyletic & $\begin{array}{l}\text { Larsson et al. (2004), Larsson (2007), loosely associated } \\
\text { with green algae }\end{array}$ \\
\hline Cyphellostereum & $\begin{array}{l}\text { Podoscyphaceae (Polyporales or polyporoid clade) or } \\
\text { Hymenochaetales (hymenochaetoid clade) }\end{array}$ & $\begin{array}{l}\text { Moncalvo et al. (2002), Redhead et al. (2002b); few weakly } \\
\text { lichenized species (Aptroot and Sipman 2001) }\end{array}$ \\
\hline Dictyonema & Hygrophoraceae (Agaricales) & $\begin{array}{l}\text { Gargas et al. (1995), Hibbett and Thorn (2001), Chaves et } \\
\text { al. (2004), Lawrey et al. (unpublished) }\end{array}$ \\
\hline Lepidostroma & Lepidostromataceae & This paper \\
\hline Lichenomphalia & Hygrophoraceae (Agaricales) & Hibbett and Thorn (2001), Redhead et al. (2002a) \\
\hline Marchandiomphalina & Corticiales & $\begin{array}{l}\text { Palice et al. (2005), Lawrey et al. (2007), Diederich and } \\
\text { Lawrey (2007), Lawrey et al. (2008) }\end{array}$ \\
\hline Multiclavula & Clavulinaceae (Cantharellales) & $\begin{array}{l}\text { Gargas et al. 1995, Lawrey et al. (2007), Nelsen et al. } \\
\text { (2007) }\end{array}$ \\
\hline Semiomphalina & Agaricales or euagarics clade & $\begin{array}{l}\text { Corner (1966), Redhead (1984), Hibbett and Thorn (2001), } \\
\text { Redhead et al. (2002a) }\end{array}$ \\
\hline
\end{tabular}

Semiomphalina spp., are only weakly lichenized, but they are important because they provide evidence of possible transitional forms. All these basidiolichens have a wide diversity of saprobic, mycorrhizal, and lichen-associated relatives (Lawrey et al., 2007; Nelsen et al., 2007).

Recent fieldwork in Rwanda (eastern Africa) led to the discovery of two new species of basidiolichens growing on soil in frequently burned savannas or on lateritic soils. Both produce a typical persistent thallus and ephemeral coral-like fruiting bodies of the Multiclavula type. They were originally described in the genus Multiclavula (as M. akagerae and M. rugaramae) based on morphological and anatomical characters only (Fischer et al., 2007). LSU sequences obtained from these species were found to be related to the Atheliales, so distantly related to $\mathrm{Mul}$ ticlavula (Cantharellales) that they were assumed at the time to be contaminations.

However, since then, two of us (J.L. and M.S.) obtained sequences of Lepidostroma calocerum, a species mentioned by Fischer et al. (2007) as a possible relative of the Rwandan species. Phylogenetic analysis of these sequences and those of the two species from Rwanda showed that they all form a well-supported monophyletic group most closely related to the Atheliales. The generic name Lepidostroma is available for it, and we assign it to the new family Lepidostromataceae. The objective of this paper is to describe this new family and to discuss its taxonomy and evolutionary significance based on a two genes phylogeny.

\section{MATERIALS AND METHODS}

Taxon sampling-Well-preserved and freshly collected lichen specimens lacking any visible symptoms of fungal infection were used for DNA isolation. We obtained 12 new sequences from five specimens belonging to three taxa of Lepidostroma from continental Africa (Rwanda) and America (Costa Rica, Mexico) (Table 2). In addition, two sequences were obtained for a specimen of Acantholichen pannarioides from the Galápagos Islands. Eighty-three sequences were added from GenBank. The four outgroup species were chosen based on Larsson (2007) and Lawrey et al. (2007): Exidiopsis calcea (Auriculariales), Exidia uvapsassa (Auriculariales), Dacrymyces sp. (Dacrymycetales) and Calocera cornea (Dacrymycetales). In total, the data set included 54 specimens representing 50 species. For the specimen of Lepidostroma rugaramae, sequences were obtained from two different DNA extractions: one from the thallus (squamules) and one from the basidiocarps.
Molecular data-Genomic DNA was isolated from lichen specimens using the Puregene Genomic DNA Purification Kit (GENTRA Systems, Minneapolis, Minnesota, USA) using the manufacturer's plant tissue extraction protocol. Amplification reactions were prepared for a $50-\mu \mathrm{L}$ final volume containing $5 \mu \mathrm{L} 10 \times$ Taq Buffer (Roche, Basel, Switzerland), $2.5 \mu \mathrm{L}$ of each of the $20 \mu \mathrm{M}$ primers, 1 $\mu \mathrm{L}$ of $10 \mathrm{mg} \cdot \mathrm{mL}^{-1}$ bovine serum albumin (\#2616, Applied Biosystems/Ambion, Austin, Texas, USA), $1 \mu \mathrm{l}$ of $25 \mathrm{mM} \mathrm{MgCl}, 1.25 \mathrm{U}$ Taq DNA polymerase (Roche) and $1 \mu \mathrm{L}$ of template genomic DNA. PCR was performed on Peltier Thermal Cyclers PTC-100 or PTC-150 (MJ Research-Biorad, Hercules, California, USA). A targeted fragment of about $0.9 \mathrm{~kb}$ at the $5^{\prime}$ end of the nuclear large subunit (nucLSU) rDNA gene was amplified using primers LROR (Rehner and Samuels, 1994), with LR5 (Vilgalys and Hester, 1990). A fragment of about 1.6 $\mathrm{kb}$ of the nuclear small subunit (nucSSU) rDNA gene was amplified and sequenced using primers NSSU97A (Kauff and Lutzoni, 2002) and NS24 (Gargas and Taylor, 1992). PCR products were purified using the QIAquick PCR Purification Kit (Qiagen, Hiklen, Germany). The yield of the PCRs was verified by running the products on a $1 \%$ agarose gel and stained with ethidium bromide. Both strands of nucLSU and nucSSU were sequenced directly using the amplification primers. Additional primers for sequencing were used: LR3R, LR3, LR5, LR5R, NSSU1088, NSSU1088R, SR7 and SR7R (Kauff and Lutzoni, 2002; Vilgalys and Hester, 1990; http://www.botany.duke.edu/fungi/mycolab). Sequence fragments were assembled with Sequencher version 4.6 (Gene Codes, Ann Arbor, Michigan, USA). Sequences were subjected to BLAST searches to verify their closest relatives and to detect potential contaminations.

Phylogenetic analyses - NucLSU and nucSSU sequences for taxa listed in Table 2 were aligned using the program MacClade version 4.05 (Maddison and Maddison, 2002). Because it was not possible to complete the nucLSU and nucSSU sequences for the same set of 50 taxa, analyses for incongruence among loci were carried out on data sets with 39 taxa for which all two genes were sequenced. Topological incongruence among data sets was examined using 1000 replicates of neighbor-joining bootstrapping (NJ-bs) with the distance measure estimated by maximum likelihood under a six-parameter (general time reversible [GTR], Rodríguez et al., 1990) "best-fit" evolutionary model for nucleotide substitution (Yang et al., 1994; Cunningham et al., 1998; Liò and Goldman, 1998) using PAUP* version 4.0b10 (Swofford, 2002). Best-fit evolutionary models were estimated for all NJ analyses using hierarchical likelihood ratio tests (LRTs) as implemented in the program Modeltest version 3.06 (Posada and Crandall, 1998). All topological bipartitions with NJ-bs values $\geq 70 \%$ were compared for all three loci. A conflict was assumed to be significant if two different relationships (one being monophyletic and the other being nonmonophyletic) for the same set of taxa were both supported with bootstrap values $\geq 70 \%$ (Mason-Gamer and Kellogg, 1996). Based on this criterion, no conflict was detected so that the LSU and SSU data sets were concatenated. A combined two-locus data set was assembled: a 50-taxon combined data set (supermatrix approach) with 11 missing sequences of the nucSSU gene.

For maximum likelihood analyses the best-fit model of DNA evolution was chosen using the Akaike information criterion (AIC) as implemented in 

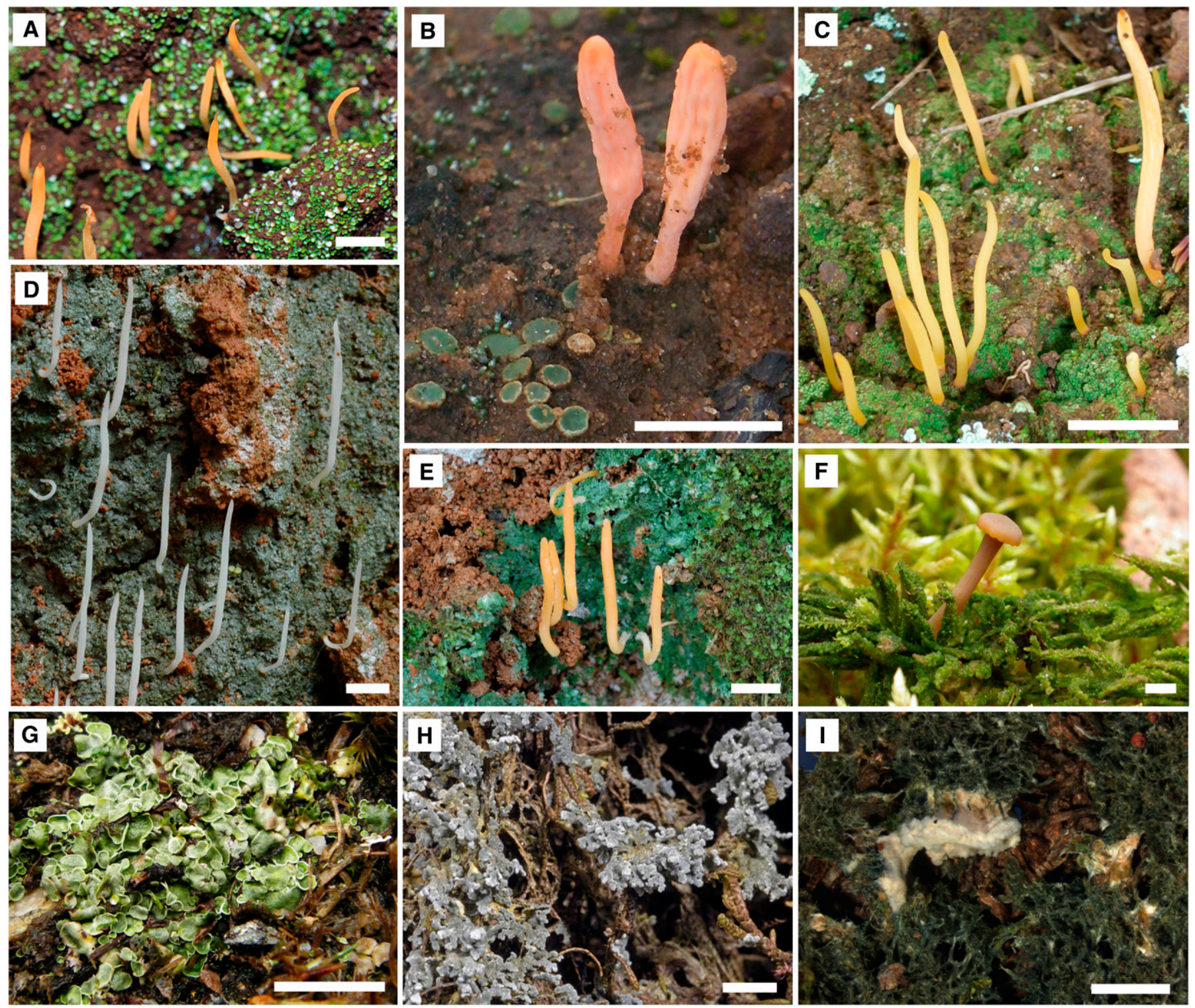

Fig. 1. Diversity of basidiolichens. (A-F) Thallus and basiodiocarps of (A) Lepidostroma calocerum (G. W. Martin) Oberw. (Costa Rica, photography by R. Lücking), (B) Lepidostroma rugaramae (Rwanda, photography by E. Fischer), (C) Lepidostroma akagerae (Rwanda, photography by E. Fischer), (D) Multiclavula cf. mucida (Pers.) R. H. Petersen (Thailand, photography by R. Walleyn), (E) Multiclavula cf. clara (Berk. \& M. A. Curtis) R. H. Petersen (Thailand, photography by R. Walleyn), and (F) Lichenomphalia umbellifera (L.) Redhead, Lutzoni with its Botrydina-type thallus overgrowing mosses and an omphalinoid basidiocarp (Belgium, photography by J.-P. Duvivier). (G) Coriscium-type thallus of Lichenomphalia hudsoniana (H. S. Jenn.) Redhead (Scotland, photography by D. Genney). (H) Acantholichen pannarioides P. M. Jørg. (Galapagos, photography by F. Bungartz). (I) Thallus and basidiocarp of Dictyonema interruptum (Carmich. ex Hook.) Parmasto (Madeira, photography by D. Ertz). Bars: (A-G) 5 mm; (H-I) 2 mm.

Modeltest version 3.06 (Posada and Crandall, 2001). Maximum likelihood (ML) searches were performed with the program GARLI version 0.95 (Zwickl, 2006). Each run was repeated three times from random starting trees using the auto-terminate setting and default parameters. The ML bootstrap replicates (significant at 70\%) were used to calculate a majority rule consensus tree in PAUP* to assess clade support. Bayesian analyses were carried out using the Metropolis-coupled Markov chain Monte Carlo method (MCMCMC) in MrBayes version 3.0b4 (Ronquist and Huelsenbeck, 2003). Analyses were run under the GTR model using a gamma-distributed rate parameter and a proportion of invariable sites. Two parallel MCMCMC runs were performed each using four chains and 5 million generations, sampling trees every 100th generation. The proportion of burn-in trees sampled before reaching equilibrium was estimated by plotting likelihood scores as a function of the number of generations. Posterior probabilities (PP) were de- termined by calculating a majority-rule consensus tree in PAUP* with the proportion of trees gathered after convergence of likelihood scores was reached, and clades with PP $\geq 0.95$ were considered to be significantly supported.

\section{RESULTS}

Phylogenetic placement of the new lineage - For the 50-taxon combined data set, the maximum likelihood analysis resulted in one optimal tree (Fig. 2) with a score of $-\operatorname{lnL}=17400.195$ using the $\mathrm{GTR}+\Gamma+\mathrm{I}$ model with nucleotide frequencies estimated $(\mathrm{A}=0.26$, 
TABLE 2. Specimens and DNA sequences for nuclear small (Nuc-SSU) and large subunit (Nuc-LSU) used in this study, with respective voucher information from GenBank. GenBank accession numbers (in boldface) refer to sequences (14) generated by this project. All other sequences (83) were obtained directly from GenBank. Vouchers generated by this study are deposited in the following herbaria: Charles Darwin Research Station (CDS), National Botanic Garden of Belgium (BR), Field Museum of Natural History (F), and University of Nebraska Omaha (OMA).

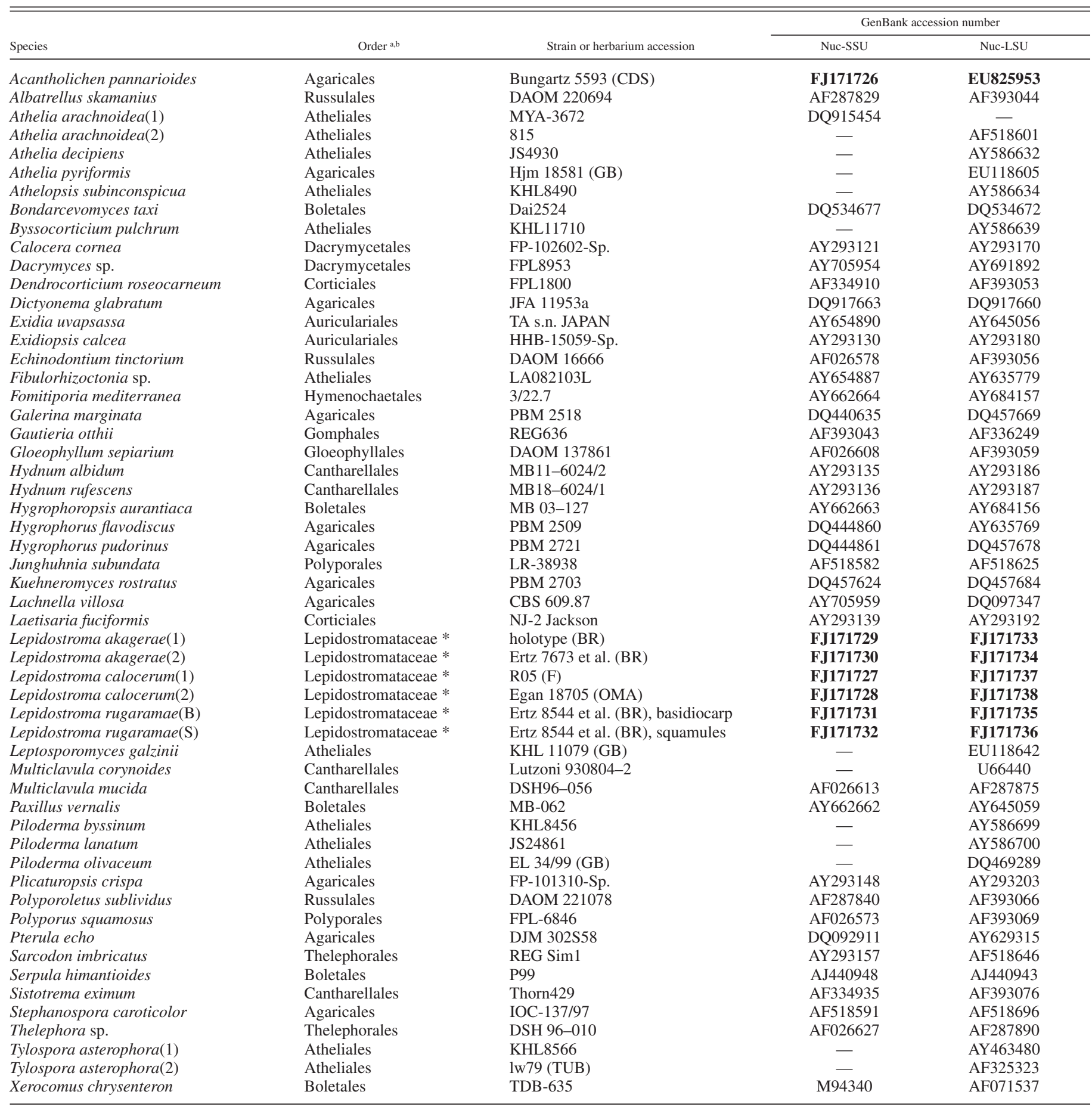

${ }^{\mathrm{a}}$ Order names are based on Matheny et al. (2006) and Larsson (2007).

${ }^{\mathrm{b}}$ The family without order affiliation is labeled Lepidostromataceae*.

$\mathrm{C}=0.20, \mathrm{G}=0.28, \mathrm{~T}=0.26)$, a rate matrix of substitutions $(\mathrm{A}-\mathrm{C}=$ $0.95, \mathrm{~A}-\mathrm{G}=3.59, \mathrm{~A}-\mathrm{T}=1.24, \mathrm{C}-\mathrm{G}=0.92, \mathrm{C}-\mathrm{T}=7.78, \mathrm{G}-\mathrm{T}=1.0)$, proportion of invariable sites $=0.55$, and $\alpha=0.55$. Bayesian runs converged after 400000 generations and 44700 trees were used to compute posterior probability values. The topology of the Bayesian consensus tree was fully consistent with that of the ML tree.

Sequences representing the four Rwandan specimens were found to combine with those of Lepidostroma calocerum in a 


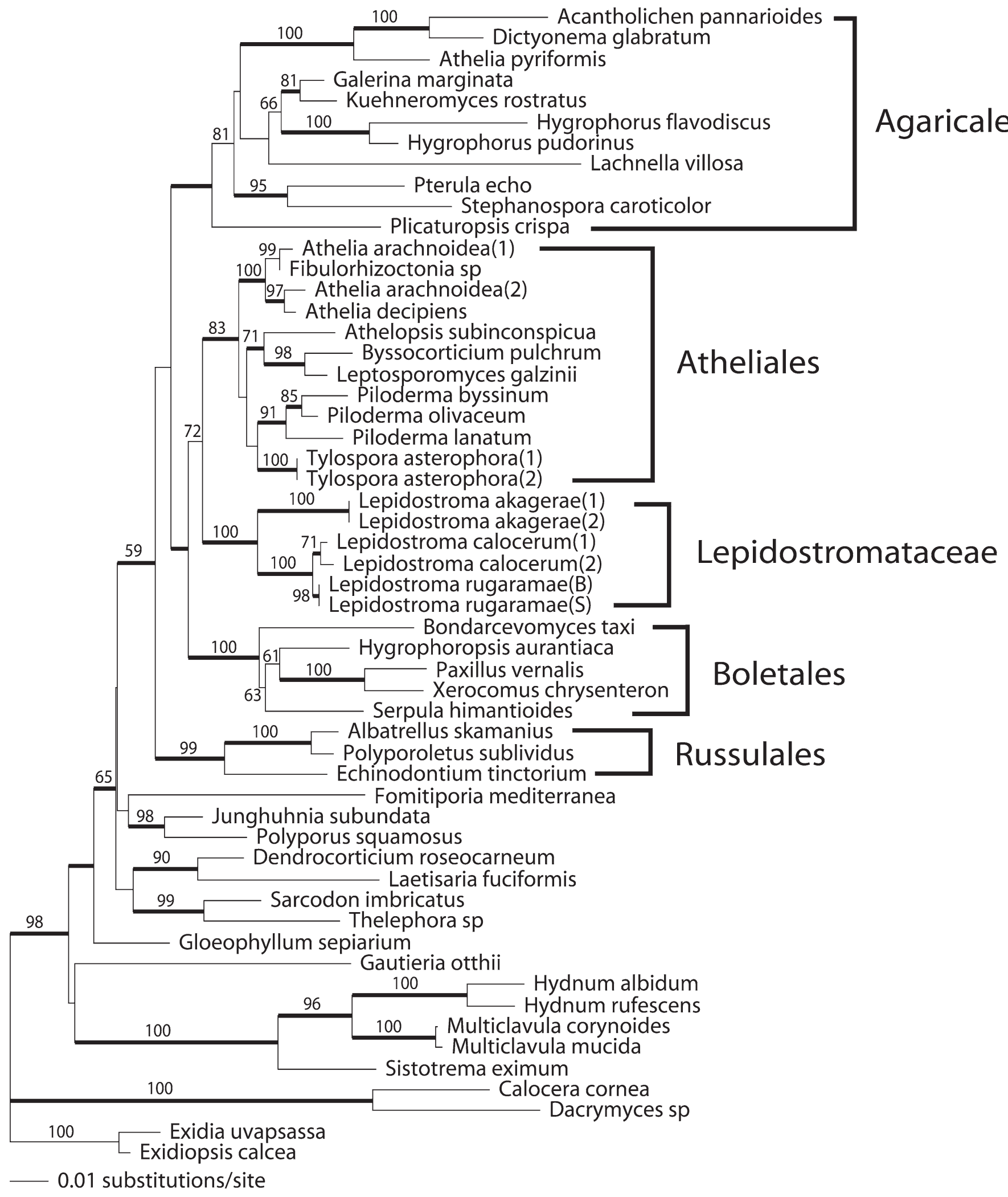

Fig. 2. Phylogenetic relationship of Lepidostroma species and their relatives to other fungi in the Agaricomycetes inferred from nuclear small and large subunit rDNA sequences using maximum likelihood. Branches in boldface indicate posterior probability values $>0.95$, maximum likelihood bootstrap support values (in \%) are provided along nodes. The labeling of the major clades of Agaricomycetes follows the Assembling the Fungal Tree of Life (AFTOL) initiative to provide a unifying classification for the kingdom Fungi (Hibbett et al., 2007). 
well-supported clade $(\mathrm{PP}=100 ; \mathrm{ML}-\mathrm{bs}=100)$ that we are calling the 'Lepidostromataceae'. Two well-supported sister groups were revealed within the Lepidostromataceae. One is represented by two specimens of L. calocerum and one specimen of $L$. rugaramae, and the second one by two specimens of $L . a k$ agerae. The Lepidostromataceae is sister to a well-supported clade represented by members of the Atheliales. The 'Lepidostromataceae' + Atheliales clade has only moderate support $(\mathrm{PP}=63 ; \mathrm{ML}-\mathrm{bs}=72)$ and is sister to a well-supported clade $(\mathrm{PP}=100 ; \mathrm{ML}-\mathrm{bs}=100)$ represented by various members of the Boletales. The Lepidostromataceae + Atheliales + Boletales are sister to representatives of the Agaricales. Relationships within the Agaricales are well supported (PP almost always $\geq$ 95; MP-bs often $\geq 97$ ). Except for the new group containing Lepidostroma spp., all these sister-group relationships are similar to those obtained by Larsson et al. (2004), Binder and Hibbett (2006), Matheny et al. (2006), and Lawrey et al. (2007).

Representatives of the more basal remaining groups were generally well supported. The Cantharellales, with five species, including the lichenized Multiclavula corynoides and $\mathrm{M}$. $\mathrm{mu}$ cida, form a monophyletic and quite well-supported group (PP = 100; ML-bs = 100) at the base of the tree. The relationships between these taxa are well resolved and supported. Different smaller groups are present between the Cantharellales and the Russulales, including the Gomphales, the Gloeophyllales, and the Hymenochaetales with one species each, the Thelephorales, the Corticiales, and the Polyporales with two species each. The relationships between them are poorly resolved. The Russulales, including three species from different genera, form a monophyletic well-supported group ( $\mathrm{PP}=98$; ML-bs =99).

Taxonomy-Family_Lepidostromataceae Ertz, Eb. Fisch., Killmann, Sérus. \& Lawrey fam. nov.

\section{MycoBank no.-MB 512318}

Type species-Lepidostroma calocerum (G. W. Martin) Oberw.; Basionym: Clavaria calocera G. W. Martin, Lilloa 5: 196 (1940).

Diagnosis-Fungi lichenisati. Thalli squamulosi, cortex ex strato singuli cellularum in visione frontali forma profunde lobata. Photobiontes chlorococcoidei. Basidiomata clavariformes, simplices. Basidia subclavata, clavato-cylindriformes, 4 sterigmatis instructis. Sporae hyalinae, tenuitunicatae, guttulatae et planae.

Specimens examined and sequenced - Costa Rica, Coto Brus County, Las Cruces Biological Station, on exposed roadside soilbank, $8^{\circ} 47^{\prime} \mathrm{N}, 82^{\circ} 57^{\prime} \mathrm{W}, 1200 \mathrm{~m}$ a.s.1., ix, 2007, R. Lücking R05 (F); Mexico, Estado de Veracruz, Sierra Madre Oriental south of Xico above the Coyopolan River, on roadside rocks and trees, $19^{\circ} 25^{\prime} 01^{\prime \prime} \mathrm{N}, 97^{\circ} 00^{\prime} 44^{\prime \prime} \mathrm{W}, 1308$ m, viii, 2007, R. Egan 18705 (OMA).

New combination-Lepidostroma akagerae (Eb. Fisch., Ertz, Killmann \& Sérus.) Ertz, Eb. Fisch., Killmann, Sérus. \& Lawrey comb. nov.

\section{MycoBank no.-MB 512321}

Basionym-Multiclavula akagerae Eb. Fisch., Ertz, Killmann \& Sérus., Bot. Journ. Linn. Soc. 155: 458 (2007).

Specimens examined and sequenced-Rwanda, province Kibungo, Akagera National Park, foot of Mt. Mutumba, open savannas and wooded gallery thickets along a small intermittent river, on open lateritic soil in burnt savanna, $01^{\circ} 38^{\prime} 51.6^{\prime \prime} \mathrm{S}$, 30³9'53.7"E, $1450 \mathrm{~m}$ a.s.1., iv.2005, D. Ertz 8556, E. Fischer,
D. Killmann \& E. Sérusiaux (holotype: BR); ibidem, prov. Butare, Butare, IRST park with isolated trees on regularly cut meadows and plantations, on earth embankment, $02^{\circ} 37^{\prime} 0.20^{\prime \prime} \mathrm{S}$, $29^{\circ} 44^{\prime} 0.45^{\prime \prime}$, c. $1690 \mathrm{~m}$ a.s.1., iii.2005, D. Ertz 7673, E. Fischer, D. Killmann \& E. Sérusiaux (BR).

New combination-Lepidostroma rugaramae (Eb. Fisch., Ertz, Killmann \& Sérus.) Ertz, Eb. Fisch., Killmann, Sérus. \& Lawrey comb. nov.

\section{MycoBank no.-MB 512322}

Basionym-Multiclavula rugaramae Eb. Fisch., Ertz, Killmann \& Sérus., Bot. Journ. Linn. Soc. 155: 461 (2007).

Specimen examined and sequenced-Rwanda, province Kibungo, quartzitic outcrops at Nyarubuye with scattered trees and vegetation, on soil, $2^{\circ} 08^{\prime} 54.0^{\prime \prime} \mathrm{S}, 30^{\circ} 44^{\prime} 44.1^{\prime \prime} \mathrm{E}, 1800 \mathrm{~m}$ a.s.1., iv.2005, D. Ertz 8544, E. Fischer, D. Killmann \& E. Sérusiaux (BR).

To summarize the morphological diagnostic differences between the species of Lepidostroma, we present an identification key at the end of the discussion.

\section{DISCUSSION}

The most striking result of this study was the extent of the phylogenetic gulf between the three species of Lepidostroma and the core group of Multiclavula species [type species: M. corynoides (Peck) R. H. Petersen] (Fig. 2). Although morphological convergence is relatively common in the Agaricomycetes, finding that the basidiolichens forming coral-like fruiting structures are not monophyletic was entirely unexpected. To our knowledge, this is the only case of two unrelated basidiolichen clades with morphologically indistinguishable fruiting structures. Even more remarkable is the finding that they form a distinct, strongly supported lineage apparently related to the Atheliales and the Boletales, two orders that do not contain obligate lichens or fungi with coral-like basidiocarps. This lineage is so distinct and strongly supported within the Agaricomycetes that we consider it to represent a new family consisting entirely of basidiolichens, which we are calling the Lepidostromataceae. Our phylogeny indicates that this family represents an origin of lichens separate from those of other recognized basidiolichens, especially those in the Agaricales, Cantharellales, and Corticiales, which appear to have evolved independently from different non-lichenized ancestors.

The species here assigned to Lepidostroma are characterized by typical coral-like basidiocarps with hymenium tissue covering the whole upper part of the basidiocarps and a permanent thallus composed of squamules with a distinct cortex (Fig. $1 \mathrm{~A}-\mathrm{C})$. The cortex is composed of a single layer of cells that have a deeply lobate shape in front view. The basidia are subclavate in L. akagerae, subclavate or clavate in L. rugaramae, or clavate-cylindrical in L. calocerum, and the spores are ovoid, usually with a distinct eccentric apiculus, colorless, thin-walled, and guttulate (Mägdefrau and Winkler, 1967; Oberwinkler, 1970, 2001; Fischer et al., 2007).

The members of the Lepidostromataceae are very similar to the genus Multiclavula (Fig. 1D, E), with coral-like basidiocarps, a simple, monomitic hyphal system, septa with clamps, a dense subhymenium, and a thickening hymenium (Oberwinkler, 2001). Petersen (1967) described the genus Multiclavula and recognized 13 species including Clavaria calocera (= now 
Lepidostroma calocerum). However, according to Oberwinkler (2001), the basidia of Lepidostroma are not suburniform and 4-6(-8)-spored as in Multiclavula, but subclavate to clavatecylindrical and always four-sterigmate. Multiclavula ichthyiformis (Nelsen et al., 2007) differs from other species assigned to Multiclavula in several important characters, including the shape and structure of the basidiocarps and in the globose rather than ellipsoid basidiospores. It also has the extranumerary (4-6) stigmata, suburniform basidia, and the lichenized bulbils characteristic of the genus Multiclavula (Poelt and Obermayer, 1990) suggesting that those characters might be more important to characterize the genus.

The thallus of Multiclavula species (especially the generic type: $M$. corynoides) is a gelatinous film with flattened to globular structures, either distinct or aggregated, containing coccomyxoid algae (Fig. 1D, E). This thallus type differs from the squamules of the three members of the Lepidostromataceae by the photobiont (coccomyxoid in Multiclavula and chlorococcoid in Lepidostroma), the absence of a distinct cortex with deeply lobate cells, and the squamule size (less than $100 \mu \mathrm{m}$ in Multiclavula; 200-500 $\mu \mathrm{m}$ in L. akagerae; $1.5-2 \mathrm{~mm}$ in L. rugaramae; $0.5-1.5 \mathrm{~mm}$ in L. calocerum). Such relatively minor differences in photobiont and thallus structure usually do not warrant family or even generic distinction in basidiomycetes. Indeed, in omphalinoid lichenized species (Omphalina Quél. s.1.), the Botrydina-type thallus (Fig. 1F) is composed of spherical glomerules with a pseudoparenchymatous outer layer, whereas the Coriscium-type thallus (Fig. 1G) is composed of flattened, tiny and fragile, corticated squamules. Molecular studies of the genus Omphalina as a whole (Lutzoni and Vilgalys, 1995; Lutzoni, 1997), clearly demonstrated that the lichenized species with Botrydina- and Coriscium-type thalli (now assigned to the separate genus Lichenomphalia) form a well-supported monophyletic clade. However, the situation is not analogous to the group Lepidostroma + Multiclavula, as both structures in the omphalinoid lichenized species enclose coccomyxoid algae, whereas different photobionts are present in Lepidostroma (chlorococcoid) vs. Multiclavula (coccomyxoid).

Together, our results therefore provide strong support for two notions that are now being discussed widely in mycology: (1) that fruit body types in Basidiomycota are much more plastic than implied by traditional classifications (Hibbett and Thorn, 2001; Moncalvo et al., 2002; Nelsen et al., 2007; Hibbett, 2007), and (2) that thallus forms must be used with great care in lichen taxonomy, as demonstrated in many ascomycetous lichens (Grube and Hawksworth, 2007).

Interestingly, the two African species of Lepidostroma do not cluster together separate from the neotropical species, as might be expected on geographical grounds. Indeed, the phylogenetic analysis shows that L. rugaramae is sister to L. calcocerum, which is presently known only from the neotropics. These two species also share a similar thallus morphology consisting of large and conspicuous squamules, whereas L. akagerae has much smaller ones. However, many tropical biomes, especially in Africa, are poorly studied and the habitat of both African species (on soil in regularly burnt savannas or laterite soils) is rarely studied by lichenologists. It is therefore premature to propose final conclusions, but the African origin of the genus is a hypothesis that should be tested in the future.

The polyphyly of the genus Athelia is here confirmed, as the species do not always cluster with members of the Atheliales, which we sampled extensively in our analyses. Athelia arachnoidea and A. decipiens are nested within the Atheliales, but
A. pyriformis is sister to the group in the Hygrophoraceae represented by the basidiolichens Acantholichen pannarioides (Fig. $1 \mathrm{H})$ and Dictyonema glabratum, suggesting a possible non-lichenized ancestral condition for Dictyonema, a large tropical group of cyanolichens (J. Lawrey et al., unpublished manuscript). However, little is known about the biological status of $A$. pyriformis, making it premature to be overly speculative about its phylogenetic position or evolutionary significance in the clade. In his study of the phylogenetic distribution of corticioid fungi, Larsson (2007) discussed the confusing taxonomic history of $A$. pyriformis, which has been assigned to three different genera at various times in the past, on each occasion illustrated again and again (Christiansen, 1960; Oberwinkler, 1965; Jülich, 1972). Larsson (2007) suggested that the best solution is to establish a separate genus in the Hygrophoraceae for this taxon.

Given the separate phylogenetic position of the Lepidostroma group in the Agaricomycetes, it is difficult to infer its ancestral condition at this point. Basal relationships among the Agaricomycete lineages, including our new family, are still poorly resolved using sequences of ribosomal genes. However, as new data are collected and these relationships are clarified, it may be possible to investigate more thoroughly the apparent convergence of characters in many unrelated basidiolichens. For example, production of lichenized granules/squamules and Multiclavula-like fruiting structures appears to have evolved separately at least twice (Cantharellales and Lepidostromataceae). Basidiolichen lineages also commonly have lichenicolous (lichen parasites) and/or sclerotial/ bulbilliferous members, suggesting possible preexisting conditions for the evolution of the lichen habit (Lawrey et al., 2007). We expect that a combined approach involving phylogenetic analysis of additional representatives of basidiolichen lineages and more thorough study of the structure, ecology, and reproductive biology of existing forms will help to elucidate both the unique pathways to lichenization taken by each lineage and the common ancestral conditions that make such transitions possible.

\section{Identification key to the basidiolichens that form coral-like fruiting} structures-

1. Thallus made of a gelatinous film, sometimes with flattened to globular structures less than $100 \mu \mathrm{m}$ in diameter; cortex with deeply lobate cells lacking; photobiont coccomyxoid; basidia suburniform Multiclavula (see identification key in Petersen [1967])

1. Thallus made of distinct squamules of $200 \mu \mathrm{m}$ to $2 \mathrm{~mm}$ in diam.; distinct cortex with deeply lobate cells present; photobiont chlorococcoid; basidia subclavate to clavate-cylindrical $\quad \mathbf{2}[$ Lepidostroma

2 . Thallus composed of discrete, turgescent, and slightly convex squamules, contiguous or irregularly lobulate, up to $0.5 \mathrm{~mm}$ in diameter L. akagerae

2. Thallus composed of dispersed, rounded to reniform squamules, $0.5-2 \mathrm{~mm}$ in diameter

3. Squamules reniform to deeply lobate, rarely rounded, without swollen whitish margin, upper surface dark green, without any paler spots or maculae, $0.5-1.5(-2.5) \mathrm{mm}$ in diameter; algal cell layer in the lower part of medulla, never forming pyramidal columns projecting upward L. calocerum

3. Squamules rounded, with a conspicuous raised and swollen margin at least when young, upper surface pale to deep green with conspicuous paler spots or maculae, $1.5-2 \mathrm{~mm}$ in diameter; algal cell layer in the lower part of medulla and projecting upwards in pyramidal columns

L. rugaramae

\section{LITERATURE CITED}

Aptroot, A., AND H. Sipman. 1991. New lichens and lichen records from New Guinea. Willdenowia 20: 221-256.

Binder, M., AND D. S. HibBetT. 2006. Molecular systematics and biological diversification of Boletales. Mycologia 98: 971-981.

Binder, M., D. S. Hibbett, K.-H. Larsson, E. Larsson, E. Langer, AND G. LANGer. 2005. The phylogenetic distribution of resupi- 
nate forms across the major clades of mushroom-forming fungi (Homobasidiomycetes). Systematics and Biodiversity 3: 113-157.

Burgess, N.,J.D'AmicoHales, E. Underwood, E. Dinerstein, D. Olson, I. ITOUA, J. SCHIPPER, et al. 2004. Terrestrial ecoregions of Africa and Madagascar. A Conservation Assessment. Island Press, Washington, D.C., USA.

Chaves, J. L., R. LÜcking, H. J. M. Sipman, L. Umaña, and E. Navarro. 2004. A first assessment of the ticolichen biodiversity inventory in Costa Rica: The genus Dictyonema (Polyporales: Atheliaceae). The Bryologist 107: 242-249.

Christiansen, M. P. 1960. Danish resupinate fungi. Part II. Homobasidiomycetes. Dansk Botanisk Arkiv 19: 57-388.

Corner, E. J. H. 1966. A monograph of cantharelloid fungi. Annals of Botany Memoir no. 2. Oxford University Press, London, UK.

Cunningham, C. W., H. Zhu, and D. M. Hillis. 1998. Best-fit maximum likelihood models for phylogenetic inference: Empirical tests with known phylogenies. Evolution 52: 978-987.

DiEderich, P., AND J. LAWREY. 2007. New lichenicolous, muscicolous, corticolous and lignicolous taxa of Burgoa s. 1. and Marchandiomyces s. 1. (anamorphic Basidiomycota), a new genus for Omphalina foliacea, and a catalogue and a key to the non-lichenized, bulbilliferous basidiomycetes. Mycological Progress 6: 61-80.

Fischer, E., D. Ertz, D. Killmann, and E. SÉrusiaux. 2007. Two new species of Multiclavula (lichenized basidiomycetes) from savanna soils in Rwanda (East Africa). Botanical Journal of the Linnean Society 155: 457-465.

Gargas, A., P. T. DePriest, M. Grube, and A. Tehler. 1995. Multiple origins of lichen symbioses in fungi suggested by SSUrDNA phylogeny. Science 268: 1492-1495.

Gargas, A., AND J. W. TAYlor. 1992. Polymerase chain reaction (PCR) primers for amplifying and sequencing $18 \mathrm{~S}$ rDNA from lichenized fungi. Mycologia 84: 589-592.

Grube, M., AND D. L. Hawksworth. 2007. Trouble with lichen: The reevaluation and re-interpretation of thallus form and fruit body types in the molecular era. Mycological Research 111: 1116-1132.

HiвBETT, D. S. 2007. After the gold rush, or before the flood? Evolutionary morphology of mushroom-forming fungi (Agaricomycetes) in the early $21^{\text {st }}$ century. Mycological Research 111: 1001-1018.

Hibiett, D. S., M. Binder, J. F. Bischoff, M. Blackwell, P. F. Cannon, O. E. ERIKSSONE, S. HuHNDORFF, et al. 2007. A higher-level phylogenetic classification of the Fungi. Mycological Research 111: 509-547.

Hibbett, D. S., and R. G. Thorn. 2001. Basidiomycota: Homobasidiomycetes. In D. J. McLauglin, E. G. McLauglin, and P. A. Lemke [eds.], The Mycota, vol. VII, part B, Systematics and evolution, 121-167. Springer-Verlag, Berlin, Germany.

Honegger, R. 1996. Mycobionts. In T. H. Nash III [ed.], The biology of lichens, 25-36. Cambridge University Press, Cambridge, UK.

JøRGENSEN, P. M. 1998. Acantholichen pannarioides, a new basidiolichen from South America. The Bryologist 101: 444-447.

JülICH, W. 1972. Monographie der Athelieae (Corticiaceae, Basidiomycetes). Willdenowia 7: 1-283.

Kauff, F., and F. Lutzoni. 2002. Phylogeny of the Gyalectales and Ostropales (Ascomycota, Fungi): Among and within order relationships based on nuclear ribosomal RNA small and large subunits. Molecular Phylogenetics and Evolution 25: 138-156.

Larsson, K.-H. 2007. Re-thinking the classification of corticioid fungi. Mycological Research 111: 1040-1063.

Larsson, K.-H., E. LaRsson, ANd U. KõLJalg. 2004. High phylogenetic diversity among corticioid homobasidiomycetes. Mycological Research 108: 983-1002.

Larsson, K.-H., E. Parmasto, M. Fischer, E. Langer, K. K. Nakasone, AND S. A. REDHEAD. 2006. Hymenochaetales: A molecular phylogeny for the hymenochaetoid clade. Mycologia 98: 926-936.

Lawrey, J. D., M. Binder, P. Diederich, M. Carmen Molina, M. SikAROOdi, ANDD.ERTZ. 2007. Phylogenetic diversity of lichen-associated homobasidiomycetes. Molecular Phylogenetics and Evolution 44: 778-789.

Lawrey, J. D., P. Diederich, M. Sikaroodi, and P. M. Gillevet. 2008. Remarkable nutritional diversity of basidiomycetes in the
Corticiales, including a new foliicolous species of Marchandiomyces (anamorphic Basidiomycota, Corticiaceae) from Australia. American Journal of Botany 95: 816-823.

Liò, P., AND N. GoldMAN. 1998. Models of molecular evolution and phylogeny. Genome Research 8: 1233-1244.

Lodge, D. J., P. B. Matheny, S. A. Cantrell, J.-M. Moncalvo, R. Vilgalys, and S. Redhead. 2006. Delineating the Hygrophoraceae: Character myths vs. gene trees. Mycological Society of America Annual Meeting Abstracts. Inoculum 57: 27.

LÜCKING, R. 2008. How many tropical lichens are there-really? IAL6 - American Bryological and Lichen Society joint meeting, Alisomar, California, USA, 2008. Abstracts available at http://www.lichenology.org/IAL6_ABLS/scientific_program.jsp.

Lutzoni, F. 1997. Phylogeny of lichen- and non-lichen-forming omphalinoid mushrooms and the utility of testing for combinability among multiple data sets. Systematic Biology 46: 373-406.

Lutzoni, F., AND R. Vilgalys. 1995. Omphalina (Basidiomycota, Agaricales) as a model system for the study of coevolution in lichens. Cryptogamic Botany 5: 71-81.

Maddison, D., AND W. Maddison. 2002. MacClade version 4.03PPC: Analysis of phylogeny and character evolution. Sinauer, Sunderland, Massachusetts, USA.

MägdefRAU, K., AND S. WinKLER. 1967. Lepidostroma terricolens n. g. n. sp., eine Basidiolichene der Sierra Nevada de Santa Marta (Kolumbien). Mitteilungen des Institute Colombo-Alemán. Investigaciones Científicas 1: $11-17$.

Martin, G. W. 1940. Some tropical American "Clavarias". Lilloa 5: 191-196.

Mason-Gamer, R. J., and E. A. Kellogg. 1996. Testing for phylogenetic conflict among molecular datasets in the tribe Triticeae (Gramineae) Systematic Biology 45: 524-545.

Matheny, P. B., J. M. Curtis, V.Hofstetter, M. C. Aime, J.-M. Moncalvo, Z.-W. GE, Z.-L. YANG, ET AL. 2006. Major clades of Agaricales: A multilocus phylogenetic overview. Mycologia 98: 982-995.

Moncalvo, J.-M., R. Vilgalys, S. A.Redhead, J.E. Johnson, T. Y.James, M. C. Aime, V. Hofstetter, S. J. W. Verduin, E. Larsson, T. J. BARONI, R.G.Thorn, S.JACOBSSON,H.CLÉMENÇON, ANDO. K. Miller JR. 2002. One hundred and seventeen clades of euagarics. Molecular Phylogenetics and Evolution 23: 357-400.

Nelsen, M. P., R. LÜCKInG, L. Umaña, M. T. Trest, S. Will-Wolf, J. L. Chaves, and A. Gargas. 2007. Multiclavula ichthyiformis (Fungi: Basidiomycota: Cantharellales: Clavulinaceae), a remarkable new basidiolichen from Costa Rica. American Journal of Botany 94: 1289-1296.

OBerwinkleR, F. 1965. Primitive Basidiomyceten Revision einiger Formenkreise von Basidienpilzen mit plastischer Basidie. Sydowia (II) 19: 1-72.

OberWInkLer, F. 1970. Die Gattungen der Basidiolichenen. Berichte der Deutschen Botanischen Gesellschaft 4: 139-169.

OBERWINKLER,F. 1984. Fungus-algainteractions in basidiolichens. Beiheft zur Nova Hedwigia 79: 739-774.

OBerwinkler, F. 2001. Basidiolichens. In B. Hock [ed.], The Mycota, vol. IX, Fungal associations, 211-225. Springer-Verlag, Berlin, Germany.

Palice, Z., I. Schmitt, AND H. T. LumbSCH. 2005. Molecular data confirm that Omphalina foliacea is a lichen-forming basidiomycete. Mycological Research 109: 447-451.

Petersen, R. H. 1967. Notes on Clavarioid fungi. VII. Redefinition of Clavaria vernalis-C. mucida complex. American Midland Naturalist 77: 205-221.

Poelt, J. AND W. JÜlich. 1969. Über die Beziehungen zweier corticioider Basidiomyceten zu Algen. Österreichische Botanische Zeitschrift 116: 400-410.

Poelt, J., ANd W. Obermayer. 1990. Lichinisierte Bulbillen als Diasporen bei der Basidiolichene Multiclavula vernalis spec. coll. Herzogia 8: 289-294.

Posada, D., and K. A. Crandall. 1998. MODElTEST: Testing the model of DNA substitution. Bioinformatics (Oxford, England) 14: $817-818$.

Posada, D., AND K. A. Crandall. 2001. Selecting the best-fit model of nucleotide substitution. Systematic Biology 50: 580-601. 
RedHEAd, S. A. 1984. Arrhenia and Rimbachia, expanded generic concepts, and a reevaluation of Leptoglossum with emphasis on muscicolous North American taxa. Canadian Journal of Botany 62: 865-892.

Redhead, S. A., F. Lutzoni, J.-M. Moncalvo, and R. Vilgalys, 2002a. Phylogeny of agarics: Partial systematics solutions for core omphalinoid genera in the Agaricales (Euagarics). Mycotaxon 83: 19-57.

Redhead, S. A., J.-M. Moncalvo, R. Vilgalys, and F. Lutzoni 2002b. Phylogeny of agarics: Partial systematics solutions for bryophilous omphalinoid agarics outside of the Agaricales (Euagarics). Mycotaxon 82: 151-168.

ReHner, S. A., AND G. J. SAmuels. 1994. Taxonomy and phylogeny of Gliocladium analysed from nuclear large subunit ribosomal DNA sequences. Mycological Research 98: 625-634.

Rodríguez, F., J. L. Oliver, A. Marín, and J. R. Medina. 1990. The general stochastic model of nucleotide substitution. Journal of Theoretical Biology 142: 485-501.
Ronquist, F., AND J. P. Huelsenbeck. 2003. MRBAYES 3: Bayesian phylogenetic inference under mixed models. Bioinformatics (Oxford, England) 19: 1572-1574.

SwOFFORD, D. L. 2002. PAUP*: Phylogenetic analysis using parsimony (*and other methods), version 4. Sinauer, Sunderland, Massachusetts, USA.

Vilgalys, R., AND M. Hester. 1990. Rapid genetic identification and mapping of enzymatically amplified ribosomal DNA from several Cryptococcus species. Journal of Bacteriology 172: 4238-4246.

YANG, Z., N. Goldman, AND A. Friday. 1994. Comparison of models for nucleotide substitution used in maximum-likelihood phylogenetic estimation. Molecular Biology and Evolution 11: 316-324.

ZwICKL, D. J. 2006. Genetic algorithm approaches for the phylogenetic analysis of large biological sequence datasets under the maximum likelihood criterion. Ph.D. dissertation, University of Texas, Austin, Texas, USA. 